Insight Microbiology 1 (3): 39-54, 2011

ISSN 2041-0387 / DOI: 10.5567/IMICRO-IK.2011.39.54

(C) 2011 Insight Knowledge, UK

\title{
Functional Aspects of Plant Growth Promoting Rhizobacteria: Recent Advancements
}

\author{
Munees Ahemad and Mohammad Saghir Khan \\ Department of Agricultural Microbiology, Faculty of Agricultural Sciences, \\ Aligarh Muslim University, Aligarh-202002, U.P., India
}

\begin{abstract}
Background: Numerous bacterial species inhabiting rhizosphere are known to exert beneficial effects upon plant growth. Such bacteria facilitating plant growth are generally referred to as plant growth promoting rhizobacteria. To exert their beneficial effects, rhizobacteria generally must colonize the root surface efficiently. This review therefore, commences with describing the bacterial traits and conditions which are required for the root colonization. Results: Several mechanisms by which microbes can act beneficially on plant growth are subsequently described. The beneficial rhizobacteria facilitate the plant growth through $\mathrm{N}_{2}$ fixation, solubilization of insoluble phosphorus, production of siderophores and production of phytohormones, lowering of ethylene concentration, production of antibiotics and antifungal metabolites and induced systemic resistance. The application of plant growth promoting rhizobacteria as bio-inoculants may be a feasible preference to chemical fertilizers to increase the productivity of various crops. Conclution: In future, the next step should be to explore the rhizobacteria (with multiple plant growth promoting properties) which might flourish well in the geographically diverse niches and to develop appropriate carriers to maintain their viability and plant beneficial activities
\end{abstract}

Key words: Plant growth promoting rhizobacteria (PGPR), indole acetic acid, siderophore, phosphate solubilization, rhizosphere

\section{INTRODUCTION}

An unanticipated amplification in agricultural practices with the aim to maximize the crop productivity at an unprecedented rate had led to exploitation of the technologies and strategies which are not in favor of the sustainability of soil health (Fox et al., 2007; Kumar et al., 2010). The excessive and ill-advised application of agro-chemicals (fertilizers and pesticides) in agricultural fields is posing grave threats to the soil fertility (Yu et al., 2009). The progressive diminution in the application of plant protectants and agrochemicals in farming practices without affecting yield or quality of the crops can only be possible with the advancement of new generation technologies. During the last couple of decades, the recent biotechnological advancements specifically in agriculture have unlocked new avenues for the augmentation of the agricultural productivity in a sustainable mode and have made possible exploitation of soil microorganisms for improving the crop health (Tank and Saraf, 2010; Khan et al., 2010) and in turn, have presented an economically feasible and ecologically sound alternative to minimize the common agricultural practices which result into decreased soil fertility and also affect the long term stability of soil ecosystem (Oves et al., 2009).
The complexity of the soil ecosystem is established by the numerous and diverse interactions among its physical, chemical and biological components (Buscot, 2005). Especially, the variable genetic and functional activities of the heterogeneous microbial populations have a vital effect on soil functions, as such microbes are considered powerful forces for specific enzyme mediated fundamental metabolic processes (Ahemad et al., 2009). Microorganisms in the soil habitat play key roles in ecosystem functioning through controlling nutrient cycling reactions essential for maintaining soil fertility and also contributing to the genesis and maintenance of soil structure (Kirk et al., 2004). Moreover, these microorganisms affect the biogeochemical cycling of nutrients and consequently help plants to grow better both under conventional and stressed soil environment (Wani et al., 2008; Khan et al., 2009). Microbial communities inhabiting soils interact with plant roots and soil constituents at the root-soil interface (Glick, 1995). And hence, the rhizosphere can be defined as any volume of soil specifically influenced by plant roots and/or in association with roots hairs and plantproduced materials (Dessaux et al., 2009). Largely, three separate but interacting components are recognized in the rhizosphere: the rhizosphere (soil), the rhizoplane and the root itself. Of these, the rhizosphere is the zone of soil

Corresponding Author: Mohammad Saghir Khan, Department of Agricultural Microbiology, Faculty of Agricultural Sciences, Aligarh Muslim University, Aligarh-202002, U.P., India Tel: +91-571-2702945 
influenced by roots through the release of substrates that affect microbial activity. The rhizoplane, on the other hand, is the root surface, including the strongly adhering soil particles (Fig. 1) while the root itself is a part of the system because certain micro-organisms (like endophytes) colonize root tissues (Bowen and Rovira, 1999). The unique physico-chemical and biological characteristics of the soils that are associated with roots, compared to the soils away from the root and root surface are responsible for the enhanced microbial diversity together with increased numbers and activity of microorganisms in the rhizosphere (Zaidi et al., 2009). During microbes-plant interaction, plant roots exude the organic materials which are used up by root associated microorganisms as nutrients as well as organic material is also supplied to the soil micro biota through the death and decay of plants as either growth substrates and structural components or signal molecules. Microbial activity in the rhizosphere affects the rooting patterns and the supply of available nutrients to plants, in a manner that modify the quality and quantity of root exudates (Gryndler, 2000).

The term rhizobacteria is used to describe a subset of rhizosphere bacteria capable of colonizing the root environment (Kloepper et al., 1991; Kloepper, 1994). Beneficial, root colonizing, rhizosphere bacteria, the PGPR (plant growth promoting rhizobacteria), are defined by three intrinsic characteristics: (i) they must be able to colonize the root (ii) they must survive and multiply in microhabitats associated with the root surface, in competition with other microbiota, at least for the time needed to express their plant growth promotion/protection activities and (iii) they must promote plant growth. Plant growth-promoting rhizobacteria are thus free-living, soil-borne bacteria which when applied to seeds/soils or crops, enhance the growth of the plant directly by providing nutrients to plants or indirectly by reducing the damage from soil-borne plant pathogens (Kloepper et al., 1980). The present review enlightens the functional aspects of PGPR, their mechanisms of plant growth promotion and their agricultural importance.

Root colonization by PGPR: The distribution, colonization, multiplication and establishment of introduced PGPR are profoundly affected by biotic and abiotic factors (Khan et al., 2010). The optimal temperature for growth of many PGPR in vitro is above $25^{\circ} \mathrm{C}$ but root colonization is generally greatest below $20^{\circ} \mathrm{C}$ (Loper et al., 1985). Better root colonization at lower temperature probably reflects the fact that microbial activity in the soil declines with temperature. Further,

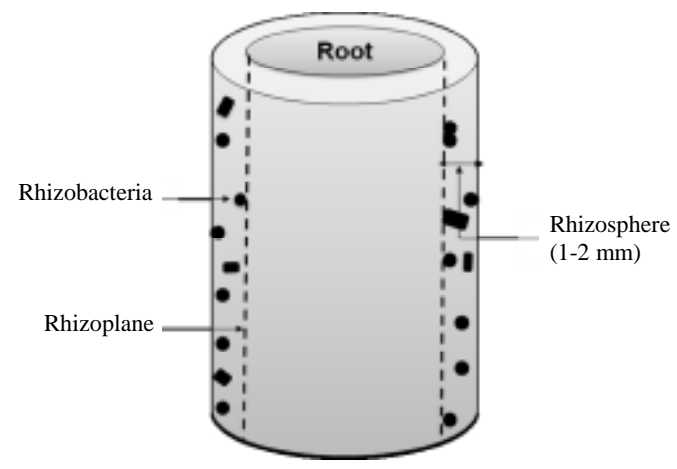

Fig. 1: Schematic representation of rhizosphere. Modified from Vega (2007)

slower root growth at lower temperatures may facilitate more effective transport of the bacteria from the inoculum source to the roots. Although PGPR grow best in vitro at neutral $\mathrm{pH}$ or above, colonization is better at lower $\mathrm{pH}$ (Edwards et al., 1998).

The biological composition of the rhizosphere dramatically influences root colonization. Accordingly, the nutrient availability rather than space is the primary determinant of microbial population size in the rhizoplane and rhizosphere (Pal, 1998; Zaidi et al., 2009). Thus, inoculation of PGPR does not lead to a change in the total rhizosphere population but a shift in the composition of the microflora such that introduced bacteria preempts establishment of the normal indigenous strains. The root colonization hence will be greater in sterile or pasteurized soils than in raw soil due to lack of competition, antibiosis and predation from the natural inhabitants of soils. In contrast, as microbial activity increases in unsterilized soils, through inputs of nutrients, the level of colonization by introduced PGPR is reduced (Casida, 1992). Pathogens that are targets of PGPR can influence PGPR populations either positively or negatively (Edwards et al., 1998).

Root colonization is a multistage event involving many bacterial traits and genes. Adhesion of PGPR to roots may be either non-specific resulting from electrostatic forces or involve glycoprotein termed agglutinin (Anderson et al., 1988). For instance, Buell and Anderson (1992) characterized a locus, agg A, from Pseudomonas that encodes a $50.5 \mathrm{kDa}$ protein required for agglutinability and adherence. Similarly, several exopolysaccharides (EPS) are reported to be involved in the attachment of rhizobacteria to plant cells and in the nodulation of legumes by Rhizobium (Cangelosi et al., 1987; Ahemad and Khan, 2010c). However, one approach to increasing root colonization by PGPR is to increase the level of bacterial inocula applied to the seeds (Bull et al., 1991). Enhancement in colonization by increasing the 
initial dose of bacteria on the seeds has, however, limitations (Osburn et al., 1989). Another strategy to increase the colonization involves the use of multiple bacterial strains; PGPR research has focussed primarily on the use of single strains. However, Weller and Cook (1983) reported that the use of P. fluorescens 2-79 in combination with $P$. fluorescens 13-79 was superior to either strain when used alone in about $50 \%$ of the trials. Furthermore, recombinant DNA technology has provided the most exciting and potentially successful means to improve root colonization and biological control by PGPR (Natsch et al., 1997).

Agricultural importance of PGPR: The PGPR belonging to various bacterial genera are known to participate in many important biological activities, such as the biological control of plant pathogens, nutrient cycling and seedling/plant growth (Persello-Cartieaux et al., 2003; Zahir et al., 2004; Ahemad and Khan, 2010d, e) through the production of various substances (Table 1). Among PGPR, Pseudomonas and Bacillus are the most commonly described genera possessing plant growth promoting activities but many other taxa are also included in PGPR group. Selected strains of PGPR are being used as seed inoculant (Sahin et al., 2004; Zahir et al., 2004; Rani et al., 2009; Ahemad and Khan, 2010f, Ahemad and Khan, 2009a).

In general, PGPR can be divided into two categories (i) extracellular PGPR (ePGPR), existing in the rhizosphere, on the rhizoplane or in the spaces between cells of the root cortex and (ii) intracellular PGPR (iPGPR) which exist inside root cells, generally in specialized nodular structures. The latter includes Rhizobia and Frankia species, both of which fix $\mathrm{N}$ in symbiosis with higher plants (Gray and Smith, 2005). Functionally, the PGPR have been separated into two groups: (i) those involved in nutrient cycling and phytostimulation (direct activity) and (ii) those involved in the biocontrol of plant pathogens (indirect activity) (Bashan and Holguin, 1998).

The use of PGPR to augment crop productivity has been limited largely due to the variability and inconsistency of results observed under laboratory, greenhouse and field trials. Soil is an unpredictable environment and an intended result is sometimes difficult to achieve. Climatic variations has also a large impact on the effectiveness of PGPR but sometimes unfavorable growth conditions in the field are to be expected as a normal functioning of agriculture (Zaidi et al., 2009). Despite all these factors, increase in crop yields following PGPR applications in the growth chambers and field trials have also been observed as presented in Table 2 .

How PGPR facilitate plant growth?: The PGPR strains facilitate growth of plants either directly or indirectly (Fig. 2) (Glick, 1995). The direct mechanism of plant growth promotion involves the production of substances by bacteria and its transport to the developing plants or facilitates the uptake of nutrients from the recipient environment (Azcon, 1989). The direct growth promoting activity of PGPR includes-(i) $\mathrm{N}_{2}$ fixation (Wani et al., $2007 \mathrm{c}$ ) (ii) solubilization of insoluble phosphorus (Khan et al., 2006, 2009) (iii) sequestering of

Table 1: Growth promoting substances released by selected PGPR

\begin{tabular}{|c|c|c|}
\hline$\underline{\text { PGPR }}$ & Plant growth promoting traits & References \\
\hline Rhizobium leguminosarum & IAA, siderophores, HCN, ammonia, exo-polysaccharides & Ahemad and Khan (2009a) \\
\hline Mesorhizobium sp. & IAA, siderophores, HCN, ammonia, exo-polysaccharides & Ahemad and Khan (2010c) \\
\hline Rhizobium sp. & IAA, siderophores, HCN, ammonia, exo-polysaccharides & Ahemad and Khan (2010d) \\
\hline Azospirillum omazonense & IAA, nitrogenase activity & Elisete et al. (2008) \\
\hline Mesorhizobium sp. & IAA, siderophores, $\mathrm{HCN}$, ammonia & Wani et al. (2008) \\
\hline Proteus vulgaris & Siderophores & Rani et al. (2009) \\
\hline $\begin{array}{l}\text { Mesorhizobium ciceri, } \\
\text { Azotobacter chroocaccum }\end{array}$ & IAA, siderophores & Wani et al. $(2007 \mathrm{c})$ \\
\hline Pseudomonas, Bacillus & Phosphate solubilization, IAA and siderophores & Wani et al. $(2007 \mathrm{c})$ \\
\hline Klebsiella oxytoca & IAA, phosphate solubilization, nitrogenase activity & Jha and Kumar (2007) \\
\hline $\begin{array}{l}\text { Bacillus spp., Pseudomonas spp., } \\
\text { Azotobacter spp., Rhizobium spp. }\end{array}$ & IAA, ammonia production & Joseph et al. (2007) \\
\hline Bradyrhizobium sp. & IAA, siderophores, HCN, ammonia & Wani et al. (2007a) \\
\hline Rhizobium sp. & IAA, siderophores, $\mathrm{HCN}$, ammonia & Wani et al. $(2007 \mathrm{~b})$ \\
\hline Pseudomonas fluorescens & Induced systemic resistance, antifungal activity & Saravanakumaretal. (2007) \\
\hline Pseudomonas chlororophis & Antifungal activity & Liu et al. (2007) \\
\hline Baciilus subtilis & Antifungal activity & Cazorla et al. (2007) \\
\hline Gluc onacetobacter diazotrophicus & Zinc solubilization & Saravanan et al. (2007) \\
\hline Brevibacillus spp. & Zn resistance, IAA & Vivas et al. (2006) \\
\hline Pseudomonas putida & Siderophores, $\mathrm{Pb}$ and $\mathrm{Cd}$ resistence & Tripathi et al. (2005) \\
\hline Pseudomonas fluorescens & IAA, siderophores, antifungal activity & Dey et al. (2004) \\
\hline $\begin{array}{l}\text { Azospirillum brasilense, } \\
\text { Azospirillum cmazonense }\end{array}$ & IAA, $P$ solubilization, nitrogenase activity, antibiotic resistance & Thakuria et al. (2004) \\
\hline Pseudomonas fluorescens & IAA, phosphate solubilization & Jeon et al. (2003) \\
\hline Kluyvera ascor bata & ACC deaminase, siderophores, metal resistance & Burd et al. (998) \\
\hline
\end{tabular}


Table 2: Examples of plant growth promoting rhizobacteria tested for various crop types

\begin{tabular}{|c|c|c|c|c|}
\hline$\underline{\text { PGPR }}$ & Plant & Conditions & Results of addition of bacteria to plants & Reference \\
\hline Pseudomonas sp. PS1 & $\begin{array}{l}\text { Greengram } \\
\text { [ Vigna radiata }(\text { L.) wilczek] }\end{array}$ & Pots & $\begin{array}{l}\text { Significantly increased plant dry weight, nodul } \mathrm{e} \backslash \\
\text { nubers, total chlorophyll content, leghaemoglobin, } \\
\text { root } \mathrm{N} \text {, shoot } \mathrm{N} \text {, root } \mathrm{P} \text {, shoot } \mathrm{P} \text {, seed } \\
\text { yield and seed protein }\end{array}$ & Ahemad and Khan (2010d) \\
\hline Rhizobium & Pea (Pisum sativum) & Pots & $\begin{array}{l}\text { When herbicide tolerant Rhizobium strain MRP1 } \\
\text { was used with herbicide, it increased the growth } \\
\text { parameters at all tested concentrations of } \\
\text { herbicides (quizalafop-p-ethyl and clodinafop). }\end{array}$ & $\begin{array}{l}\text { Ahemad and Khan } \\
(2009 \mathrm{~b})\end{array}$ \\
\hline $\begin{array}{l}\text { Rhizobium } \\
\text { leguminosarum } \\
\text { strain MRP1 }\end{array}$ & Pea (Pisum sativum) & Pots & $\begin{array}{l}\text { Significantly increased the growth, symbiotic } \\
\text { properties (nodulation and leghaemoglobin content), } \\
\text { amount of } N \text { and } P \text { nutri ents in plant organs, seed } \\
\text { yield and seed protein of pea plants }\end{array}$ & Ahemad and Khan (2010a) \\
\hline $\begin{array}{l}\text { Mesorhizobium } \\
\text { strain MRC4 }\end{array}$ & Chickpea (Cicer arietinum) & Pots & $\begin{array}{l}\text { Significantly increased symbiotic properties } \\
\text { (nodulation and leghaemoglobin content), root } \mathrm{N} \text {, } \\
\text { shoot } \mathrm{N} \text {, root } \mathrm{P} \text {, shoot } \mathrm{P} \text {, seed } \\
\text { yield and seed protein }\end{array}$ & $\begin{array}{l}\text { AhemadandKhan (2009a), } \\
\text { Ahemad and Khan (2010c) }\end{array}$ \\
\hline $\begin{array}{l}\text { Pseudomnas putida } \\
\text { strain R-168, }\end{array}$ & Maize (Zea mays L.) & Fields & $\begin{array}{l}\text { Plant height, seed weight, number of seed per ear } \\
\text { and leaf area, shoot dry weight significantly }\end{array}$ & Gholami et al. (2009) \\
\hline
\end{tabular}

Pseudomonas fluorescens

strain R-93, Pseudomonas

fluorescens DSM 50090,

Pseudomonas putida

DSM291, Azospirillum

lipoferum DSM 1691 ,

Azospirillum brasilense

DSM 1690

Azotobacter chroococcum,

Azospirillum lipoferum

(Gossypium hirsutum L.)

Seed yield (21\%), plant height (5\%) and microbial

population in soil $(41 \%)$ increased over their respective

controls while boll weight and staple length remained statistically unaffected

Pseudomonas putida

CC-R2-4, Bacillus

Lectuca sativa $\mathrm{L}$.

subtilis CC-pg104

Azospirillum amazonense

Rice (Oryza sativa L.).

Gnotobiotic Significant increase in shoot length and root length

conditions achieved through encapsulated inoculant

Greenhouse Grain dry matter accumulation ( 7 to $11.6 \%$ ), the number of panicles ( 3 to $18.6 \%$ ) and nitrogen

accumulation at grain maturation (3.5

to $18.5 \%$ ) increased

Pseudomonas species

Rice (Oryza sativa),

Pseudomonad isol ated from rice showed a higher

ability to control bacterial and fungal root pathogens

than that obtained from maize

Azospirillum brasilense Common bean

Sp245

(Phaseolus vulgaris L.)

Peanut

Pseudomonas fluorescens

(Arachis hypogaea L.)

PGPR1, PGPR2, PGPR4

Rice (Oryza sativa)

Barley (Hordeum vulgare)

Bacillus pantothenticus,

Pseudomonas pieketti

Bacillus spp.

Bacillus subtilis

Solanum lycopersicum

L. (tomato), Abelmoschus

esculentus (okra), Amaranthus

sp. (African spinach)

Pseudomonas aeruginosa

Solanum lycopersicum

L. (tomato), Abelmoschus

esculentus (okra), Amaranthus

sp. (African spinach)

Unidentified PGPR

wheat

In vitro

Root growth increased

Pots, fields Significantly enhanced pod yield, haulm yield and nodule dry weight over the control

Micro-plots Increased rice grain yiel d maximum upto $76.9 \%$

Greenhouse Increased root weight upto $16.7 \%$ and shoot weight upto $347 \%$

Greenhouse Dry bi omass increased $31 \%$ for tomato, $36 \%$ for okra and $83 \%$ for African spinach

Anjum et al. (2007)

Rekha et al. (2007)

Elisete et al. (2008)

Lawongsa $e t$ al. (2008)

Remans et al. (2008)

Dey et al. (2004)

Thakuria et al. (2004)

Canbolat et al. (2006)

Adesemoye et al. (2008)

Greenhouse Dry biomass increased $31 \%$ for tomato, $29 \%$ for okra and $40 \%$ for African spinach

Adesemoye et al. (2008)

Gnotobiotic Increases in root elongation (up to $17.3 \%$ ), root dry

conditions weight (up to 13.5\%), shoot elongation (up to 37.7\%) and shoot dry weight (up to $36.3 \%$ ) in inoculated wheat seedlings

Bradyrhizobium sp. $\quad$ Greengram $\quad$ Pots $\quad$ Enhanced the nodule numbers by $82 \%$, leghaemoglobin by $120 \%$, seed yi eld by $34 \%$, grain protein by $13 \%$, root $\mathrm{N}$ by $41 \%$ and shoot $\mathrm{N}$ by $37 \%$ at $290 \mathrm{mg} \mathrm{Ni} \mathrm{kg}{ }^{-1}$ soil.
Increased the dry matter accumulation, number of nodule

Mesorhizobium sp.

Chickpea

Pots seed yield and grain protein by $71,86,36$ and $16 \%$, respectively, compared to noninocul ated plants. Nitrogen in roots and shoots increased by 46 and $40 \%$, respectively, at $136 \mathrm{mg} \mathrm{Cr} / \mathrm{kg}$.

Rhizobium sp.

Pea

Pots

RP5 Enhanced the dry matter, nodule numbers, root $\mathrm{N}$, shoot $\mathrm{N}$, leghaemoglobin, seed yield and grain protein by 19,23 , $26,47,112,26$ and $8 \%$, respectively, at $290 \mathrm{mg} \mathrm{Ni} \mathrm{kg}^{-1}$

Wani et al. (2007a)

Wani et al. (2008)

Wani et al. (2007b) 


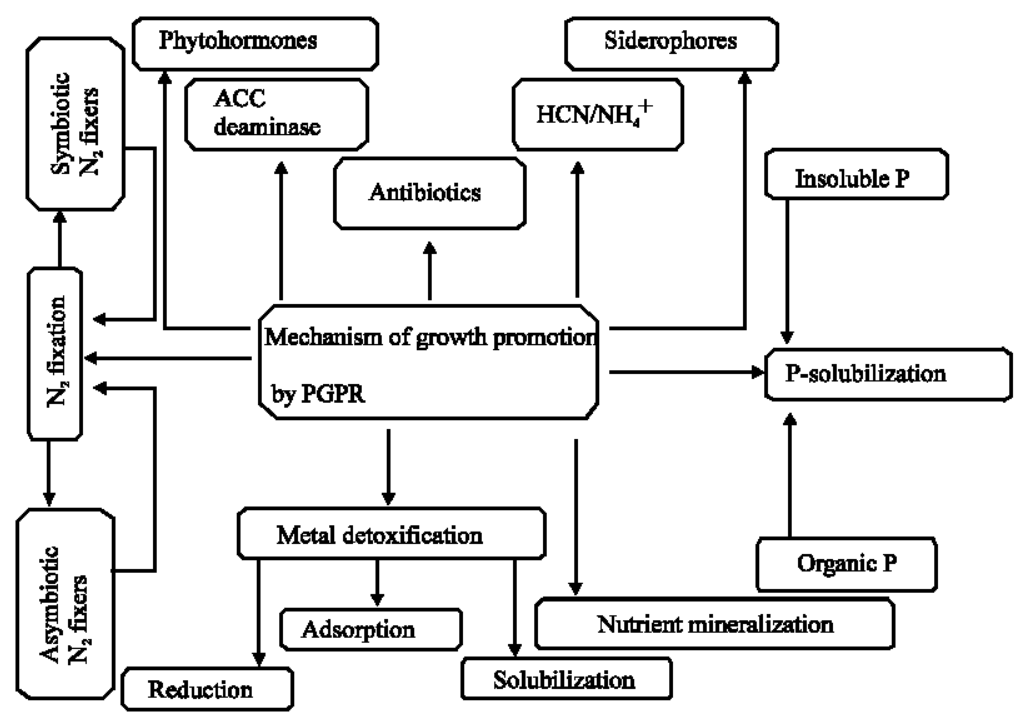

Fig. 2: A general scheme showing how PGPR promote plant growth

iron by production of siderophores (Wani et al., 2008; Rajkumar et al., 2006) (iv) production of phytohormones such as, auxins, cytokinins, gibberellins and (v) lowering of ethylene concentration (Liu et al., 2007; Elisete et al., 2008; Wani et al., 2008). On the contrary, the indirect mechanism of plant growth promotion by PGPR includes (i) antibiotic production (ii) depletion of iron from the rhizosphere (iii) synthesis of antifungal metabolites (iv) production of fungal cell wall lysing enzymes (v) competition for sites on roots and (vi) induced systemic resistance (Saravanakumar et al., 2007; Cazorla et al., 2007). Briefly, the indirect promotion of plant growth takes place when PGPR lessen or prevent the injurious effects of plant pathogens by synthesizing inhibitory substances or by increasing the natural resistance of the host to the pathogens.

\section{Direct mechanisms of action}

Nitrogen fixation: Nitrogen $(\mathrm{N})$ is one of the most common nutrients required for optimal plant growth and productivity. Even though, more than $78 \%$ of $\mathrm{N}$ is present in the atmosphere, yet it remains unavailable to growing plants. It therefore, needs to be converted into ammonia, an available form to plants and other eukaryotes. Atmospheric $\mathrm{N}$ is converted into plant utilizable forms by three different processes: (a) conversion of atmospheric $\mathrm{N}$ into oxides of $\mathrm{N}$ in the atmosphere (b) industrial $\mathrm{N}$ fixation that involves the use of catalysts and high temperature $\left(300-500^{\circ} \mathrm{C}\right)$ to transform $\mathrm{N}$ into ammonia and (c) Biological N Fixation (BNF) which changes the nitrogen to ammonia by microorganisms using a complex enzyme system known as nitrogenase (Kim and
Rees, 1994). Of all the processes, BNF fixes about $60 \%$ of the earth's available $\mathrm{N}$ and represents an economically beneficial and environmentally sound alternative to chemical fertilizers (Ladha et al., 1997).

Nitrogen fixing organisms can broadly be divided as: (a) symbiotic $\mathrm{N}_{2}$ fixing bacteria, that includes members of family rhizobiaceae and forms symbiosis with leguminous host plants (e.g., rhizobia) (Zahran, 2001; Ahemad and Khan, 2010a, c, d) and non-leguminous trees (e.g., Frankia). Gram-negative soil bacteria (rhizobia) within the rhizobiaceae phylogenetic family ( $\alpha$-proteobacteria) possess the unique ability to infect and establish a nitrogen-fixing symbiosis with the roots of leguminous plants. The establishment of the symbiosis involves a complex interplay between host and symbiont (Giordano and Hirsch, 2004) resulting in the formation of a novel organ, the nodule which the bacteria colonize as intracellular symbionts (b) non-symbiotic (free living, associative and endophytes) nitrogen fixing forms such as cyanobacteria (Anabaena, Nostoc), Azospirillum, Azotobacter, Gluconoacetobacter diazotrophicus and Azocarus etc. Plant growth-promoting rhizobacteria that fix $\mathrm{N}_{2}$ in non-leguminous plants are also called as diazotrophs capable of forming a non-obligate interaction with the host plants (Glick et al., 1999). The process of $\mathrm{N}_{2}$ fixation is carried out by the nitrogenase enzyme coded by nif genes (Kim and Rees, 1994). Nitrogenase was elucidated by Dean and Jacobson (1992) as a twocomponent metalloenzyme consisting of (i) dinitrogenase reductase which is the iron protein and (ii) dinitrogenase which has a metal cofactor. Based on the metal cofactor three different $\mathrm{N}$ fixing systems have been identified (a) 
Mo-dinitrogenase (b) V-nitrogenase and (c) $\mathrm{Fe}$ nitrogenase. The existence of the $\mathrm{N}_{2}$ fixing system differs among bacterial genera (Bishop and Joerger, 1990).

Phytohormones: Another direct mechanism by which PGPR facilitates plant growth is the production of plant growth regulators or phytohormones (Glick, 1995; Wani et al., 2008; Ahemad and Khan, 2009a; Ahemad and Khan, 2010a). Frankenberger and Arshad (1995) have discussed in detail the role of auxins, cytokinins, gibberellins, ethylene and Abscisic Acids (ABA) which when applied to plants, have shown a substantial increase in growth and yield of plants. The production of phytohormones such as, auxins (IAA), cytokinins and gibberellins by natural soil microbial communities have been reported by various workers over the last 20 years (Poonguzhali et al:; 2008, Ahemad and Khan, 2010g, h).

As an example, the production of Indole-3-Acetic Acid (IAA) by microorganisms in the presence of the precursor tryptophan or peptone has been reported (Wani et al., 2008; Ahmad et al., 2008). Indole-3-acetic acid, a main auxin in plants is known to control many important physiological processes of plants, such as, cell enlargement, cell division, root initiation, growth rate, phototropism, geotropisms and apical dominance etc., (Zaidi et al., 2009). In plant cells, IAA is largely formed by de novo synthesis from tryptophan which undergoes either oxidative deamination (via the formation of indole-3pyruvic acid) or decarboxylation (via the formation of tryptamine with indole-3-acetic aldehyde as an intermediate.

The synthesis of IAA by microbes involves one of the three pathways as presented in Fig. 3 (Patten and Glick, 1996): (1) IAA formation via indole-3-pyruvic acid and indole-3-acetic aldehyde is found in the majority of bacteria like, Erwinia herbicola; saprophytic species of the genera Agrobacterium and Pseudomonas; certain representatives of Bradyrhizobium, Rhizobium, Azospirillum, Klebsiella and Enterobacter (2) The conversion of tryptophan into indole-3-acetic aldehyde may involve an alternative pathway in which tryptamine is formed. This pathway is believed to operate in pseudomonads and azospirilla and (3) IAA biosynthesis via indole-3-acetamide formation is reported for phytopathogenic bacteria Agrobacterium tumefaciens, Pseudomonas syringae and E. herbicola; saprophytic pseudomonads like (e.g., Pseudomonas putida and P. fluorescens). The genes controlling IAA synthesis via this pathway are also reported in symbiotic bacteria (e.g., Rhizobium spp., Bradyrhizobium spp. and Azospirillum spp.), although the activity of the corresponding enzymes is either negligible or not detectable. (4) IAA biosynthesis that involves tryptophan conversion into indole-3acetonitrile is found in plants, Alcaligenes faecalis and possibly the cyanobacterium (Synechocystis sp.) and (5) The tryptophan-independent pathway, more common in plants, is also found in microorganisms (azospirilla and cyanobacteria). However, the synthesis of IAA using this pathway is reported to be insignificant and the mechanisms are largely unknown.

Many bacteria are known to synthesize auxins using such pathways and help the plants to grow better. In this context, rhizospheric microflora colonizing plant roots are of paramount importance in the conversion of tryptophan into IAA. And hence, the removal of tryptophan from the culture medium leads to decrease in the level of IAA by the microorganisms. However, the amount of the auxins formed depends primarily on the composition of the medium and the conditions (e.g., temperature, aeration, etc.) of bacterial growth. Bacteria in general, forms maximum amount of IAA during the steady-state stage of their growth while ammonium ions and glutamine inhibit IAA biosynthesis (Tsavkelova et al., 2006). The genes involved in IAA synthesis in bacterial strains may be plasmid or chromosomal borne. For example, pathogenic bacteria contain Ti plasmids that control the formation of the phytohormone whereas in saprophytic microorganisms, auxin biosynthesis is governed by chromosomal genes (Tsavkelova et al., 2006).

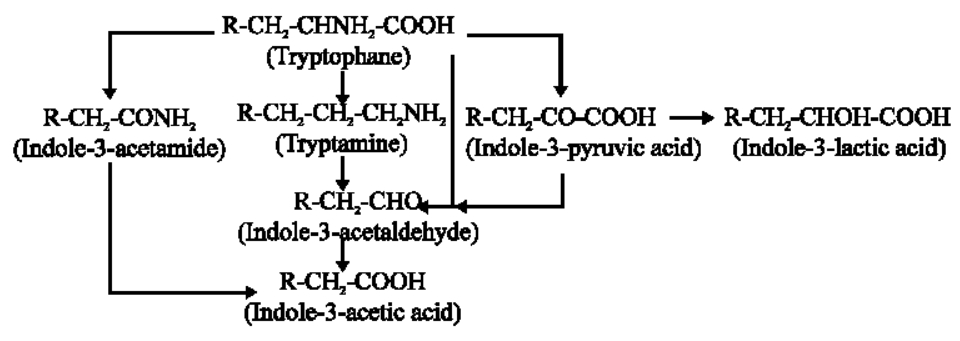

Fig. 3: Biosynthetic pathways of IAA synthesis in bacteria 
It is reported that $80 \%$ of microorganisms isolated from the rhizosphere of various crops possess the ability to synthesize and release auxins as secondary metabolites(Loper and Schroth, 1986). Of the various PGPR strains, bacteria belonging to the genera Azospirillum, Pseudomonas, Xanthomonas and Rhizobium as well as Alcaligenes, Enterobacter, Acetobacter, Klebsiella and Bradyrhizobium have been shown to produce auxins which help in stimulating plant growth (Wani et al., 2007a; Poonguzhali et al., 2008; Kumar et al., 2008; Ahemad and Khan, 2010b, g, h). However, the extent of IAA production by bacterial strains could be different due in part to the involvement of biosynthetic pathways, location of the genes, regulatory sequences and the presence of enzymes to convert active free IAA into conjugated forms. Moreover, the synthesis of IAA is also influenced by environmental factors (Patten and Glick, 1996). Synthesis of IAA by Rhizobium spp. in the presence and absence of tryptophan has also been demonstrated (Wani et al., 2007b). Bent et al. (2001) reported that the concentration of indole compounds by three different strains, Paenibacillus polymyxa (L6), P. polymyxa (Pw-2) and Pseudomonas fluorescens (M20) increased with increasing rate of tryptophan $\left(0-200 \mathrm{mg} \mathrm{mL}^{-1}\right)$ at different incubation interval.

Microbial phosphate solubilization: Phosphorus (P), a major plant nutrient is required for various metabolic processes such as, energy transfer, signal transduction, macro-molecular biosynthesis, photosynthesis and respiration (Khan et al., 2009). Phosphorus however, is also one of the major nutrients limiting plant growth (Fernandez et al., 2007). Worldwide, 5.7 billion hectares land contain too little available $\mathrm{P}$ for sustaining optimal crop production. Phosphorus ion concentration in most soils ranges from 0.1 to $10 \mu \mathrm{M}$; P required for optimal growth ranges from 1 to $5 \mu \mathrm{M}$ for grasses and 5 to $60 \mu \mathrm{M}$ for high demanding crops such as tomato (Lycopersicum esculentum) and pea (Pisum sativum) (Raghothama, 1999). Sub-optimal levels of $\mathrm{P}$, can however, lead to a 5 to $15 \%$ losses in the yield of crops (Khan et al., 2009). Phosphorus is present in the soils both in organic and inorganic forms (Fig. 4). Of which, organic forms, as found in humus and other organic materials including decayed plant, animal and microbial tissues, is an important reservoir of immobilized $\mathrm{P}$ accounting for about $20-80 \%$ of total soil P (Richardson, 1994). Phosphorus in labile organic compounds can be slowly mineralized as available inorganic $\mathrm{P}$ or it can be immobilized as part of the soil organic matter (McKenzie and Roberts, 1990). Soil inorganic $\mathrm{P}$ is however, controlled mainly by solution $\mathrm{pH}$ and the concentration of cations and in most soils, maximum $\mathrm{P}$ availability occurs between $\mathrm{pH} 5.5$ to 7 . Within this $\mathrm{pH}$ range, $\mathrm{P}$ is fixed by hydrous oxides of $\mathrm{Fe}, \mathrm{Al}$ and $\mathrm{Mn}$ while between $\mathrm{pH} 6$ to 8 and $\mathrm{pH} 6.5$ to $8.5, \mathrm{P}$ is fixed by silicate minerals and $\mathrm{Ca}$, respectively. As a consequence, the most efficient use of $\mathrm{P}$ in neutral and calcareous soils occurs between $\mathrm{pH} 6$ to 7 .

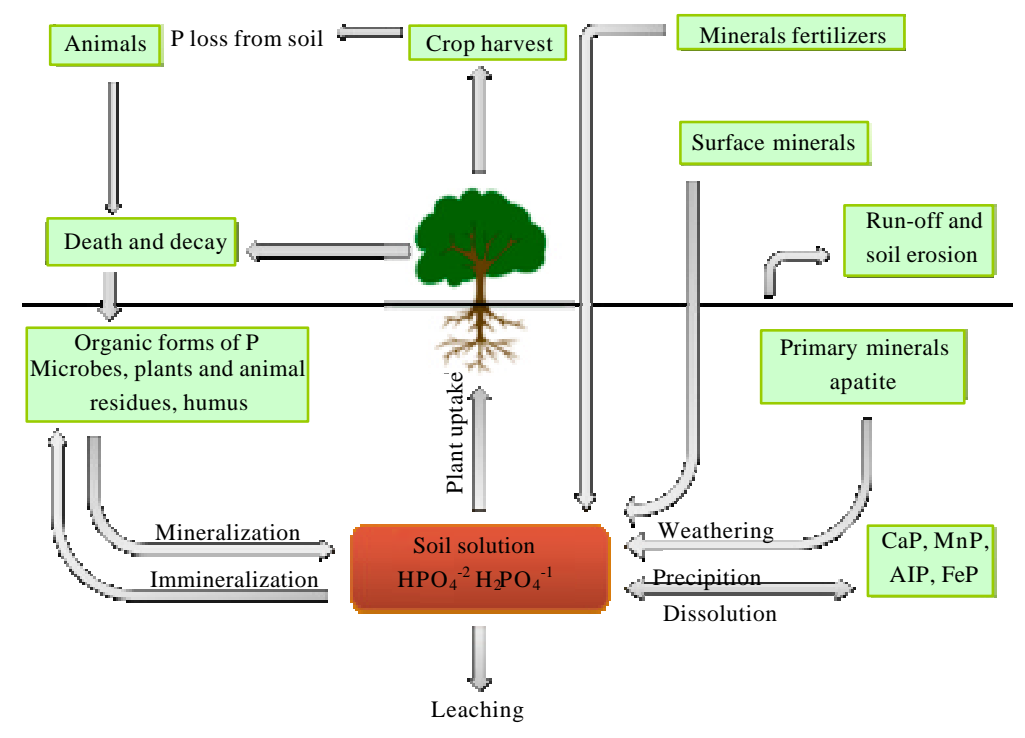

Fig. 4: Movement of phosphorus in soils 
However, the majority of $\mathrm{P}$ is unavailable for uptake by plants due to its rapid rate of fixation/complex formation with other elements of soils. Therefore, phosphatic fertilizers are applied to soil to replenish the $\mathrm{P}$ demands of growing plants. However, a large portion of soluble inorganic $\mathrm{P}$ applied to the soil as fertilizer is immobilized rapidly and becomes unavailable to plants (Goldstein, 1986). Moreover, the concentration of soluble $\mathrm{P}$ in soil solution is very low $\left(400-1,200 \mathrm{mg} \mathrm{kg}^{-1}\right.$ of soil) (Ehrlich, 1990; Rodriguez and Fraga, 1999). Attempts to overcome the $\mathrm{P}$ deficiency by applying phosphatic fertilizers is expensive and ecologically unsafe practice because the efficiency of the added $\mathrm{P}$ fertilizer is as low. This has led to search environment-friendly and economically feasible alternative strategies for improving crop production in low $\mathrm{P}$ soils. In this study, organisms endowed with phosphate solubilizing activity, often termed Phosphate Solubilizing Microorganisms (PSM), may provide the available forms of $\mathrm{P}$ to the plants and hence a viable substitute to chemical phosphatic fertilizers (Khan et al., 2006). Of the various PSM (s) inhabiting rhizosphere, Phosphate-Solubilizing Bacteria (PSB) are considered as promising biofertilizers since they can supply plants with $\mathrm{P}$ from sources otherwise poorly available by various mechanisms (Fig. 5) (Khan et al., 2006). Though, PSB are commonly found in most soils (Wani et al., 2007c; Ahemad and Khan, 2010h); their establishment and performances are severely affected by environmental factors especially under stress conditions (Wani et al., 2007c; Ahemad and Khan, 2010g). However, the beneficial effects of the inoculation with PSB used alone (Poonguzhali et al., 2008; Chen et al., 2008; Ahemad and Khan, 2010b, f) or in combination with other rhizospheric microbes have been reported (Zaidi and Khan, 2005; Zaidi and Khan, 2006; Vikram and Hamzehzarghani, 2008).

Besides providing $\mathrm{P}$ to the plants, the PS bacteria also augment the growth of plants by stimulating the efficiency of BNF, enhancing the availability of other trace elements (such as iron, zinc) and by synthesizing important plant growth promoting substances (Ponmurugan and Gopi, 2006; Mittal et al., 2008) (Table 3) including siderophores (Vassilev et al., 2006; Wani et al., 2008), antibiotics (Fernando et al., 2006) and providing protection to plants against soil borne pathogens (biocontrol). Accordingly, these bacterial communities when used either singly (Chen et al., 2008) or as consortia, in combination with other rhizosphere microbes (Mishra et al., 2009) have shown a substantial improvement in crop productivity in different agroecosystems.

Siderophores: Iron-chelating molecules termed siderophores are generally less than 1000 molecular weight and are produced by many microorganisms. More than 500 different siderophores, mostly produced by Gram-positive and Gram-negative bacteria (Wani et al., 2007a; Ahemad and Khan, 2010a, b), have been described. Despite this great variety, most have a peptide backbone with several non-protein amino acid analogs including

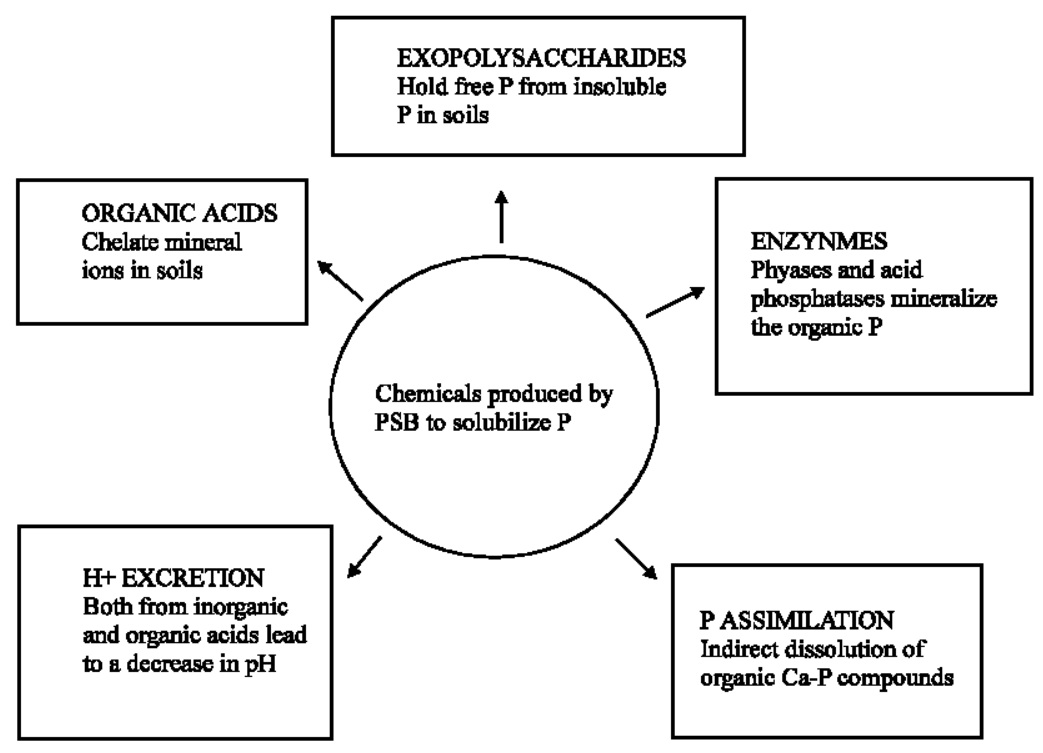

Fig. 5: Mechanisms of $\mathrm{P}$ solubilization by phosphate solubilizing bacteria 
Insight Microbiology 1 (3): 39-54, 2011

Table 3: Growth promoting substances released by phosphate solubilizing bacteria

\begin{tabular}{|c|c|c|}
\hline Phosphate solubilizing bacteria & Plant growth promoting traits & References \\
\hline Pseudomonas aeruginosa PS1 & IAA, siderophores, HCN, ammonia, exo-polysaccharides & $\begin{array}{l}\text { Ahemad and Khan (2010b), } \\
\text { Ahemad and Khan (2010f) }\end{array}$ \\
\hline Klebsiella sp. & IAA, siderophores, HCN, ammonia, exo-polysaccharides & Ahemad and Khan $(2010 \mathrm{~g})$ \\
\hline Enterobacter asburiae & IAA, siderophores, HCN, ammonia, exo-polysaccharides & $\begin{array}{l}\text { Ahemad and Khan (2010h), } \\
\text { Ahemad and Khan (2010I) }\end{array}$ \\
\hline Pseudomonas sp. & ACC deaminase, IAA, siderophore & Poonguzhali et al. (2008) \\
\hline Bacillus subtilis & IAA, siderophore, antifungal activity & Singh et al. (2008) \\
\hline Serratia marcescens & IAA, siderophore, $\mathrm{HCN}$ & Selvakumar et al. (2008) \\
\hline Pseudomonas fluorescens & ACC deaminase & Shaharoona et al. (2008) \\
\hline Acinetobacter sp., Pseudomonas sp. & ACC deaminase, IAA, antifungal activity, $\mathrm{N}_{2}$ fixation & Indiragandhi et al. (2008) \\
\hline Enterobacter sp. & ACC deaminase, IAA, siderophore & Kumar et al. (2008) \\
\hline Burkholderia & ACC deaminase, IAA, siderophore, heavy metal solubilization & Jiang et al. (2008) \\
\hline Pseudomonas jessenii & ACC deaminase, IAA, siderophore, heavy metal solubilization & Rajkumar and Freitas (2008) \\
\hline Pseudomonas aeruginosa & ACC deaminase, IAA, siderophore & Ganesan (2008) \\
\hline Pseudomonas sp. & ACC deaminase, IAA, siderophore, heavy metal solubilization & Rajkumar and Freitas (2008) \\
\hline $\begin{array}{l}\text { Azotobacter sp., Mesorhizobium sp., } \\
\text { Pseudomonas sp., Bacillus } \text { sp. }\end{array}$ & IAA, siderophore, antifungal activity, ammonia production, $\mathrm{HCN}$ & Ahmad et al. (2008) \\
\hline Bacillus spp. & $\begin{array}{l}\text { IAA, siderophores, ammonia production, } \mathrm{HCN} \text {, } \\
\text { chromium reduction, metal solubilization }\end{array}$ & Wani et al. $(2007 \mathrm{a}, \mathrm{b}, \mathrm{c})$ \\
\hline Bacillus subtilis & IAA & Zaidi et al. (2006) \\
\hline Pseudomonas sp., Bacillus sp. & IAA, siderophore & Rajkumar et al. (2006) \\
\hline Pseudomonas putida & Antifungal activity, siderophore, $\mathrm{HCN}$ & Pandey et al. (2006) \\
\hline $\begin{array}{l}\text { Pseudomonas fluorescens } \mathrm{PRS}_{9} \text {, } \\
\text { Pseudomonas fluorescens } \mathrm{GRS}_{1}\end{array}$ & IAA, siderophores & Gupta et al. (2005) \\
\hline
\end{tabular}

both modified and D-amino acids. In general, rhizosphere bacteria differs with respect to siderophore cross-utilizing abilities; some are proficient at using siderophores of the same genus (homologous siderophores) while others could utilize siderophores produced by other rhizospheric bacteria of different genera (heterologous siderophores) (Khan et al., 2009).

Siderophore production and utilization by rhizobacteria is of particular interest due to the dominant role of iron in the nitrogen fixation and assimilation process. The iron enzymes involved include nitrogenase, leghemoglobin, ferredoxin and hydrogenase with nitrogenase and leghemoglobin constituting up to 12 and $30 \%$ of total protein in the bacterial and infected plant cells, respectively (Verma and Long, 1983).

Siderophores chelate iron with high affinity (the calculated affinity constant being above $10^{30} \mathrm{M}^{-1}$ ). Siderophores are highly electronegative and bind Fe (III), preferentially forming a hexacoordinated complex. The iron ligation groups have been tentatively classified into three main chemical types: hydroxamate (e.g., aerobactin and ferrichrome), catechol rings (e.g., enterobactin) and hydroxyacid (e.g., pyochelin). Some siderophores contain more than one of these three iron-chelating groups (Stintzi et al., 2000).

In Gram-negative bacteria, the ferric-siderophore complex must cross the outer membrane and the cytoplasmic membrane before delivering iron within the cytoplasm. The ferric complexes are too large for passive diffusion or nonspecific transport across these membranes (Stintzi et al., 2000); ferric-siderophore uptake is both receptor and energy dependent. Translocation of

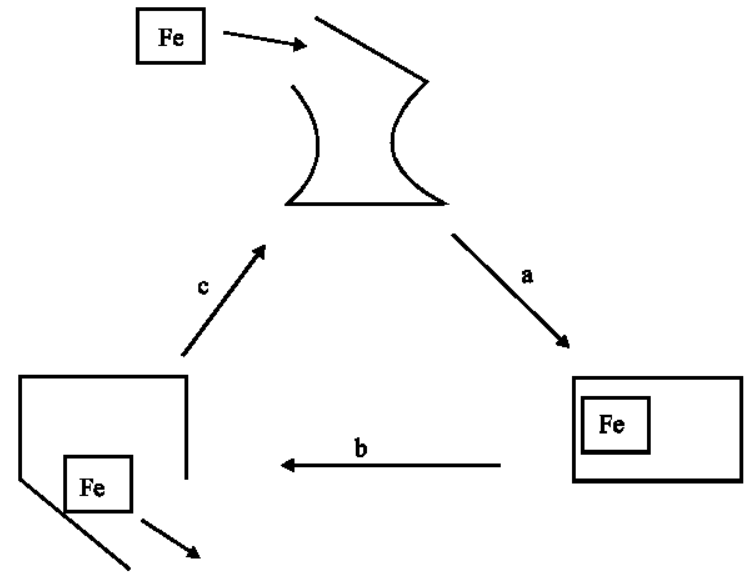

Fig. 6: The usual siderophore iron delivery mechanism. Adopted from Stintzi et al. (2000)

iron through the bacterial outer membrane as the ferricsiderophore requires the formation of an energy transducing complex with the proteins TonB, ExbB and ExbD which couple the electrochemical gradient across the cytoplasmic membrane to a highly specific receptor and so promote transport of the iron complex across the outer membrane (Stintzi et al., 2000). Once in the periplasmic space, the ferric-siderophore binds to its cognate periplasmic binding protein and is then actively transported across the cytoplasmic membrane by an ATPtransporter system. Two mechanisms have been proposed (i) the usual siderophore iron delivery mechanism (Fig. 6): (a) ferric siderophore is bound to the protein receptor, 


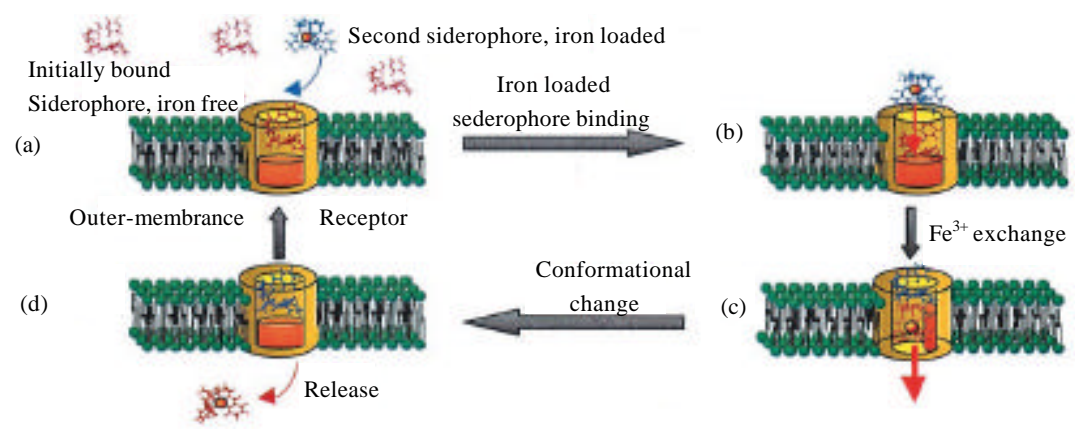

Fig.7: The siderophore shuttle iron delivery mechanism. Adopted from Stintizi et al. (2002)

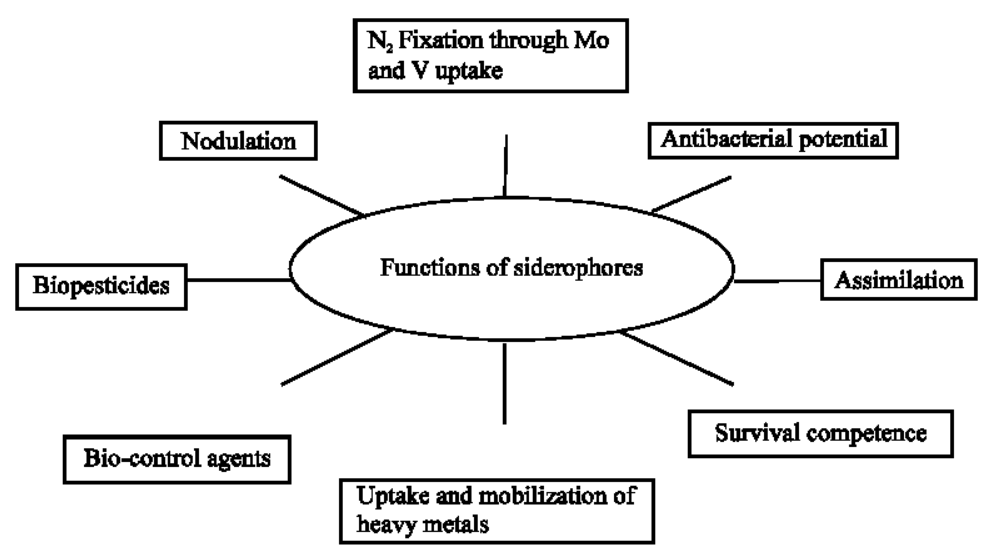

Fig. 8: Impact of microbially secreted siderophores on plant growth

causing a conformational change in the protein (b) the ferric siderophore is pumped through the receptor into the periplasmic space and (c) on release of the ferric siderophore, the receptor protein returns to its original conformation and (ii) the siderophore shuttle iron delivery mechanism (Fig. 7): (a) with the iron-free siderophore initially bound to the receptor protein, a second, ironloaded siderophore binds to the receptor (b) iron exchange between the two siderophores occurs (c) this iron exchange causes a conformational change and the iron complex of the originally iron-free siderophore enters the cytoplasm (d) on release of the ferric siderophore, the receptor protein returns to its original conformation, now with the originally iron-loaded siderophore bound to the receptor protein (Stintzi et al., 2000).

One of the suggested modes of growth promotion of nodulated legumes under field conditions is by microbial production of siderophores which facilitate the uptake of iron from the environment (Ahemad and Khan, 2010c, d). The effects of microbial siderophores on growth and development of plants are presented in Fig. 8. A nodulated legume has been found to have an increased demand for iron compared to that of a non-nodulated plant (Derylo and Skorupska, 1993). For example, Pseudomonas sp. strain 267 enhanced symbiotic $\mathrm{N}_{2}$ fixation in clover under gnotobitoic conditions, produced fluorescent siderophores under low-iron conditions and secreted B group vitamins (Kozaczuk and Skorupska, 2001).

However, Tn5 insertion mutants of strain 267 defective in siderophore production did not differ from the wild-type in promoting the growth of clover (Medicago sativa) suggesting that the siderophore production had no effect on stimulating nodulation. In contrast, Gill et al. (1991) demonstrated that mutants of Rhizobium melioti that were unable to produce siderophores were able to nodulate the plants but the efficiency of $\mathrm{N}_{2}$ fixation was less compared to the wild-type, indicating the importance of iron in $\mathrm{N}_{2}$ fixation. In a similar study, Kluyvera ascorbata, a siderophore-producing PGPR was able to protect plants from heavy metal toxicity (Burd et al., 1998). 


\section{CONCLUSION}

The discussion clearly demonstrated that PGPR adopt different mechanisms to promote the plant growth and these rhizobacteria due to versatile plantbeneficial traits are promising the environment-friendly tools for sustainable agriculture. Due to a great variation in soil ecology of different regions, no single PGPR can be used universally as a bio-inoculant. Hence, the next step should be to explore the rhizobacteria (with multiple plant growth promoting properties) which might flourish well in most of the geographical niches. In this context, the optimization of PGPR inoculums must be rigorously tested in the presence of diverse biotic and/or abiotic factors. In addition, to maintain the maximum viability and activities of PGPR, an appropriate carrier should be developed.

\section{ACKNOWLEDGMENTS}

Authors are thankful for the financial assistance from University Grants Commission (UGC), New Delhi.

\section{REFERENCES}

Adesemoye, A.O., M. Obini and E.O. Ugoji, 2008. Comparison of plant growth-promotion with Pseudomonas aeruginosa and Bacillus subtilis in three vegetables. Braz. J. Microbiol., 39: 423-426.

Ahemad, M. and M.S. Khan, 2009a. Effect of insecticidetolerant and plant growth-promoting Mesorhizobium on the performance of chickpea grown in insecticide stressed alluvial soils. J. Crop Sci. Biotechnol., 12: 213-222.

Ahemad, M. and M.S. Khan, 2009b. Toxicity assessment of herbicides quizalafop-p-ethyl and clodinafop towards Rhizobium pea symbiosis. Bull. Environ. Contam. Toxicol., 82: 761-766.

Ahemad, M. and M.S. Khan, 2010a. Pseudomonas aeruginosa strain PS1 enhances growth parameters of greengram [Vigna radiata (L.) Wilczek] in insecticide-stressed soils. J. Pest Sci., 84: 123-131.

Ahemad, M. and M.S. Khan, 2010b. Ameliorative effects of Mesorhizobium sp. MRC4 on chickpea yield and yield components under different doses of herbicide stress. Pestic. Biochem. Physiol., 98: 183-190.

Ahemad, M. and M.S. Khan, 2010c. Comparative toxicity of selected insecticides to pea plants and growth promotion in response to insecticide-tolerant and plant growth promoting Rhizobium leguminosarum. Crop Prot., 29: 325-329.
Ahemad, M. and M.S. Khan, 2010d. Growth promotion and protection of lentil (Lens esculenta) against herbicide stress by Rhizobium species. Ann. Microbiol., 60: 735-745.

Ahemad, M. and M.S. Khan, 2010e. Influence of selective herbicides on plant growth promoting traits of phosphate solubilizing Enterobacter asburiae strain PS2. Res. J. Microbiol., 5: 849-857.

Ahemad, M. and M.S. Khan, 2010f. Insecticide-tolerant and plant-growth-promoting Rhizobium improves the growth of lentil (Lens esculentus) in insecticidestressed soils. Pest Manage. Sci., 67: 423-429.

Ahemad, M. and M.S. Khan, 2010g. Phosphatesolubilizing and plant-growth-promoting Pseudomonas aeruginosa PS1 improves greengram performance in quizalafop-p-ethyl and clodinafop amended soil. Arch. Environ. Contam. Toxicol., 58: $361-372$.

Ahemad, M. and M.S. Khan, 2010h. Plant growth promoting activities of phosphate-solubilizing Enterobacter asburiae as influenced by fungicides. Eur. Asian J. Biosci., 4: 88-95.

Ahemad, M. and M.S. Khan, 2010i. Toxicological effects of selective herbicides on plant growth promoting activities of phosphate solubilizing Klebsiella sp. strain PS19. Curr. Microbiol., 62: 532-538.

Ahemad, M., A. Zaidi, M.S. Khan and M. Oves, 2009. Factors Affecting the Variation of Microbial Communities in Different Agro-Ecosystems. In: Microbial Strategies for Crop Improvement, Khan, M.S., A. Zaidi and J. Musarrat (Eds.). Springer, Berlin, Heidelberg, pp: 301-324.

Ahmad, F., I. Ahmad and M.S. Khan, 2008. Screening of free-living rhizospheric bacteria for their multiple plant growth promoting activities. Microbiol. Res., 168: 173-181.

Anderson, A.J., P. Habibadegah-Tari and C.S. Tepper, 1988. Molecular studies on the role of a root surface agglutinin in adherence and colonization by Pseudomonas putida. Applied Environ. Microbiol., 54: 375-380.

Anjum, M.A., M.R. Sajjad, N. Akhtar, M.A. Qureshi, A. Iqbal, A.R. Jami and Mahmud-ul-Hasan, 2007. Response of cotton to Plant Growth Promoting Rhizobacteria (PGPR) inoculation under different levels of nitrogen. J. Agric. Res. Pak., 45: 135-142.

Azcon, R., 1989. Selective interaction between free-living rhizosphere bacteria and vesicular-arbuscular mycorrhizal fungi. Soil Biol. Biochem., 21: 639-644.

Bashan, Y. and G. Holguin, 1998. Proposal for the division of plant growth-promoting rhizobacteria into two classifications: Biocontrol-PGPB (plant growthpromoting bacteria) and PGPB. Soil Biol. Biochem., 30: $1225-1228$. 
Bent, E., S. Tuzun, C.P. Chanway and S. Enebak, 2001. Alterations in plant growth and in root hormone levels of lodgepole pines inoculated with rhizobacteria. Can. J. Microbiol., 47: 793-800.

Bishop, P.E. and R.D. Joerger, 1990. Genetics and molecular biology of an alternative nitrogen fixation system. Plant Mol. Biol., 41: 109-125.

Bowen, G.D. and A.D. Rovira, 1999. The rhizosphere and its management to improve plant growth. Adv. Agron., 66: 1-102.

Buell, C.R. and A.J. Anderson, 1992. Genetic analysis of the agg $\mathrm{A}$ locus involved in agglutination and adherence of Pseudomonas putida, a beneficial fluorescent pseudomond. Mol. Plant Microbe. Interact., 5: 154-162.

Bull, C.T., D.M. Weller and L.S. Thomashow, 1991. Relationship between root colonization and suppression of Gaeumannomyces graminis var. tritici by Pseudomonas fluorescens strain 2-79. Phytopathology, 81: 954-959.

Burd, G.I., D.G. Dixon and B.R. Glick, 1998. A plant growth-promoting bacterium that decreases nickel toxicity in seedlings. Applied Environ. Microbiol., 64: 3663-3668.

Buscot, F., 2005. What are Soils. In: Micro-Organisms in Soils: Roles in Genesis and Functions, Buscot, F. and A. Varma (Eds.). Springer-Verlag, Heidelberg, Germany, pp: 3-18.

Canbolat, M.Y., S. Bilen, R. Cakmakc, F. Sahin and A. Aydin, 2006. Effect of plant growth-promoting bacteria and soil compaction on barley seedling growth, nutrient uptake, soil properties and rhizosphere microflora. Biol. Fertil. Soils, 42: 350-357.

Cangelosi, G.A., L. Hung, V. Puvanesarajah, G. Stacey, D.A. Ozga, J.A. Leigh and E.W. Nester, 1987. Common loci for Agrobacterium tumefaciens and Rhizobium meliloti exopolysaccharide synthesis and their roles in plant interactions. J. Bacteriol., 169: 2086-2091.

Casida, L.E. Jr., 1992. Competitive ability and survival in soil of Pseudomonas strain 679-2, a dominant, nonobligate bacterial predator of bacteria. Applied Environ. Microbiol., 58: 32-37.

Cazorla, F.M., D. Romero, A. Perez-Garcia, B.J.J. Lugtenberg, A. de Vicente and G. Bloemberg, 2007. Isolation and characterization of antagonistic Bacillus subtilis strains from the avocado rhizoplane displaying biocontrol activity. J. Applied Microbiol., 103: 1950-1959.

Chen, Z., S. Ma and L.L. Liu, 2008. Studies on phosphorus solubilizing activity of a strain of phosphobacteria isolated from chestnut type soil in China. Bioresour. Technol., 99: 6702-6707.
Dean, D.R. and M.R. Jacobson, 1992. Biochemical Genetics of Nitrogenase. In: Biological Nitrogen Fixation, Stacey, G., R.H. Burris and H.J. Evans (Eds.). Chapman and Hall, New York, pp: 763-834.

Derylo, M. and A. Skorupska, 1993. Enhancement of symbiotic nitrogen fixation by vitamin-secreting fluorescent Pseudomonas. Plant Soil, 154: 211-217.

Dessaux, Y., P. Hinsinger and P. Lemanceau, 2009. Rhizosphere: So many achievements and even more challenges. Plant Soil, 321: 1-3.

Dey, R., K.K. Pal, D.M. Bhatt and S.M. Chauhan, 2004. Growth promotion and yield enhancement of peanut (Arachis hypogaea L.) by application of plant growth-promoting rhizobacteria. Microbiol. Res., 159: 371-394.

Edwards, S.G., J.P.W. Young and A.H. Fitter, 1998. Interactions between Pseudomonas fluorescens biocontrol agents and Glomus mosseae, an arbuscular mycorrhizal fungus, within the rhizosphere. FEMS Microbiol. Lett., 166: 297-303.

Ehrlich, H.L., 1990. Mikrobiologische, Biochemische Verfahrenstechnik. In: Geomicrobiology, Einsele, A., R.K. Finn and W. Samhaber (Eds.). 2nd Edn., VCH Verlegsgesllschaft, Weinheim.

Elisete, P.R., S.R. Luciana, L.M.D.O. Andre, D.B.V. Lucia, D.S.T.K. Regina, U. Segundo and M.R. Veronica, 2008. Azospirillum amazonense inoculation: Effects on growth, yield and $\mathrm{N}_{2}$ fixation of rice (Oryza sativa L.). Plant Soil, 302: 249-261.

Fernandez L.A., P. Zalba, M.A. Gomez and M.A. Sagardoy, 2007. Phosphate-solubilization activity of bacterial strains in soil and their effect on soybean growth under green house conditions. Biol. Fertil Soils, 43: 803-805.

Fernando, W.G.D., S. Nakkeeran and Z. Yilan, 2006. Biosynthesis of Antibiotics by PGPR and its Relation in Biocontrol of Plant Diseases. In: PGPR: Biocontrol and Biofertilization, Siddiqui, Z.A. (Ed.). Springer, Dordrecht, The Netherlands, ISBN-13: 9781402040023 , pp: 67-109.

Fox, J.E., J. Gulledge, E. Engelhaupt, M.E. Burow and J.A. McLachlan, 2007. Pesticides reduce symbiotic efficiency of nitrogen-fixing rhizobia and host plants. PNAS, 104: 10282-10287.

Frankenberger, Jr. W.T. and M. Arshad, 1995. Phytohormones in Soil: Microbial Production and Function. Marcel Dekker Inc., New York, USA., ISBN: $0824794427, \mathrm{pp}: 503$.

Ganesan, V., 2008. Rhizoremediation of cadmium soil using a cadmium-resistant plant growth-promoting rhizopseudomonad. Curr. Microbiol., 56: 403-407. 
Gholami, A., S. Shahsavani and S. Nezarat, 2009. The effect of Plant Growth Promoting Rhizobacteria (PGPR) on germination, seedling growth and yield of Maize. World Acad. Sci. Eng. Technol., 49: 19-24.

Gill, J.P.R., L.L. Barton, M.D. Scoble and J.B. Neilands, 1991. A high-affinity iron transport system of Rhizobium meliloti may be required for efficient nitrogen fixation in plants. Plant Soil, 130: 211-217.

Giordano, W. and A.M. Hirsch, 2004. The expression of MaEXP1, a Melilotus alba expansin gene, is upregulated during the sweetclover-Sinorhizobium meliloti interaction. Mol. Plant Microbe. Interact., 17: 613-622.

Glick, B.R., 1995. The enhancement of plant growth by free-living bacteria. Can. J. Microbiol., 41: 109-117.

Glick, B.R., C.L. Patten, G.Holguin and D.M. Penrose, 1999. Biochemical and Genetic Mechanisms Used by Plant Growth Promoting Bacteria. Imperial College Press, London, UK.

Goldstein, A.H., 1986. Bacterial solubilization of mineral phosphates: Historical perspective and future prospects. Am. J. Alternative Agric., 1: 51-57.

Gray, E.J. and D.L. Smith, 2005. Intracellular and extracellular PGPR: Commonalities and distinctions in the plant-bacterium signaling processes. Soil Biol. Biochem., 37: 395-412.

Gryndler, M., 2000. Interactions of Arbuscular Mycorrhizal Fungi with other Soil Organisms. In: Arbuscular Mycorrhizas: Physiology and Function, Kapulnik, Y. and D.D. Douds, Jr. (Eds.). Kluwer Academic Publishers, Dordrecht, Netherlands, pp: 239-262.

Gupta, A., V. Rai, N. Bagdwal and R. Goel, 2005. In situ characterization of mercury-resistant growthpromoting fluorescent pseudomonads. Microbiol. Res., 160: 385-388.

Indiragandhi, P., R. Anandham, M. Madhaiyan and T.M. Sa, 2008. Characterization of plant growthpromoting traits of bacteria isolated from larval guts of diamondback moth Plutella xylostella Lepidoptera: Plutellidae. Curr. Microbiol., 56: 327-333.

Jeon, J.S., S.S. Lee, H.Y. Kim, T.S. Ahn and H.G. Song, 2003. Plant growth promotion in soil by some inoculatedmicroorganisms. J. Microbiol., 41: 271-276.

Jha, P.N. and A. Kumar, 2007. Endophytic colonization of Typha australis by a plant growth-promoting bacterium Klebsiella oxytoca strain GR-3. J. Applied Microbiol., 103: 1311-1320.

Jiang, C., X. Sheng, M. Qian and Q. Wang, 2008. Isolation and characterization of a heavy metal-resistant Burkholderia sp. from heavy metal-contaminated paddy field soil and its potential in promoting plant growth and heavy metal accumulation in metalpolluted soil. Chemosphere, 72: 157-164.
Joseph, B., R.R. Patra and R. Lawrence, 2007. Characterization of plant growth promoting rhizobacteria associated with chickpea (Cicer arietinum L.). Int. J. Plant Prod., 2: 141-152.

Khalid, A., M. Arshad and Z.A. Zahir, 2004. Screening plant growth-promotiong Rhizobacteria for improving growth and yield of wheat. J. Applied Microbio., 96: 473-480.

Khan, M.S., A. Zaidi and P.A. Wani, 2006. Role of phosphate-solubilizing microorganisms in sustainable agriculture-A review. Agron. Sustainable Dev., 27: 29-43.

Khan, M.S., A. Zaidi, P.A. Wani, M. Ahemad and M. Oves, 2009. Functional Diversity among Plant Growth-Promoting Rhizobacteria. In: Microbial Strategies for Crop Improvement, Khan, M.S., A. Zaidi and J. Musarrat (Eds.). Springer, Berlin, Heidelberg, pp: 105-132.

Khan, M.S., A. Zaidi, M. Ahemad, M. Oves and P.A. Wani, 2010. Plant growth promotion by phosphate solubilizing fungi-current perspective. Arch. Agron. Soil Sci., 56: 73-98.

Kim, J. and D.C. Rees, 1994. Nitrogenase and biological nitrogen fixation. Biochemistry, 33: 389-397.

Kirk, J.L., L.A. Beaudette, M. Hart, P. Moutoglis, J.N. Klironomous, H. Lee and J.T. Trevors, 2004. Methods of studying soil microbial diversity. J. Microbiol. Methods, 58: 169-188.

Kloepper, J.W., J. Leong, M. Teintze and M.N. Schroth, 1980. Enhanced plant growth by siderophores produced by plant growth promoting rhizobacteria. Nature, 286: 885-886.

Kloepper, J.W., R.M. Zablotowics, E.M. Tipping and R. Lifshitz, 1991. Plant Growth Promotion Mediated by Bacterial Rhizosphere Colonizers. In: The Rhizosphere and Plant Growth, Keister, D.L. and P.B. Cregan (Eds.). Kluwer Academic Publishers, USA., pp: 315-326.

Kloepper, J.W., 1994. Plant Growth-Promoting Rhizobacteria (Other Systems). In: Azospirillum/Plant Associations Okon, Y. (Eds.). CRC Press, Boca Raton, FL., USA., pp: 111-118.

Kozaczuk, M.M. and A. Skorupska, 2001. Production of B-group vitamins by plant growth-promoting Pseudomonas fluorescens strain 267 and the importance of vitamins in the colonization and nodulation of red clover. Biol. Fertil. Soils, 33: 146-151.

Kumar, K.V., N. Singh, H.M. Behl and S. Srivastava, 2008. Influence of plant growth promoting bacteria and its mutant on heavy metal toxicity in Brassica juncea grown $\mathrm{n}$ fly ash amended soil. Chemosphere, 72: 678-683. 
Kumar, J.I.N., A. Bora and M.K. Amb, 2010. Chronic toxicity of the triazole fungicide tebuconazole on a heterocystous, nitrogen-fixing rice paddy field cyanobacterium, Westiellopsis prolifica Janet. J. Microbiol. Biotechnol., 20: 1134-1139.

Ladha, J.K., F.J. de Brujin and K.A. Malik, 1997. Introduction assessing opportunities for nitrogen fixation in rice a frontier project. Plant Soil, 194: 1-10.

Lawongsa, P., N. Boonkerd, S. Wongkaew, F. O'Gara and N. Teaumroong, 2008. Molecular and phenotypic characterization of potential plant growth-promoting Pseudomonas from rice and maize rhizospheres. World J. Microbiol. Biotechnol., 24: 1877-1884.

Liu, H., Y. He, H. Jiang, H. Peng and X. Huang et al., 2007. Characterization of a phenazine-producing strain Pseudomonas chlororaphis GP72 with broadspectrum antifungal activity from green pepper rhizosphere. Curr. Microbiol., 54: 302-306.

Loper, J.E., C. Haack and M.N. Schroth, 1985. Population dynamics of soil pseudomonas in the rhizosphere of potato (Solanum tuberosum L.). Applied Environ. Microbiol., 49: 416-422.

Loper, J.E. and M.N. Schroth, 1986. Influence of bacterial sources of indole-3-acetic acid on root elongation of sugar beet. Phytopathol., 76: 386-389.

McKenzie, R.H. and T.L. Roberts, 1990. Soil and fertilizers phosphorus update. Proceedings of the Alberta Soil Science Workshop, Feb. 20-22, Edmonton, Alberta, pp: 84-104.

Mishra, P.K., S. Mishra, G. Selvakumar, J.K. Bisht, S. Kundu and H.S. Gupta, 2009. Coinoculation of Bacillus thuringeinsis-KR1 with Rhizobium leguminosarum enhances plant growth and nodulation of pea (Pisum sativum L.) and lentil (Lens culinaris L.). World J. Microbiol. Biotechnol., 25: 753-761.

Mittal, V., O. Singh, H. Nayyar, J. Kaur and R. Tewari, 2008. Stimulatory effect of phosphate-solubilizing fungal strains (Aspergillus awamori and Penicillium citrinum) on the yield of chickpea (Cicer arietinum L. cv. GPF2). Soil Biol. Biochem., 40: 718-727.

Natsch, A., C. Keel, N. Hebecker, E. Laasik and G. Mago, 1997. Influence of biocontrol strain Pseudomonas fluorescens $\mathrm{CHAO}$ and its antibiotic overproducing derivative on the diversity of resident root colonizing pseudomonads. FEMS Microbiol. Ecol., 23: 341-352.

Osburn, R.M., M.N. Schroth, J.G. Hancock and M. Hendson, 1989. Dynamics of sugar beet seed colonization by Pythium ultimum and Pseudomonas species: Effects on seed rot and damping-off. Phytopathology, 79: 709-716.
Oves, M., A. Zaidi, M.S. Khan and M. Ahemad, 2009. Variation in Plant Growth Promoting Activities of Phosphate-Solubilizing Microbes and Factors Affecting their Colonization and Solubilizing Efficiency in Different Agro-Ecosystems. In: Phosphate Solubilizing Microbes for Crop Improvement, Khan, M.S. and A. Zaidi (Eds.). Nova Science Publishers Inc., New York, USA., pp: 247-263.

Pal, S.S., 1998. Interactions of an acid tolerant strain of phosphate solubilizing bacteria with a few acid tolerant crops. Plant Soil, 198: 169-177.

Pandey, A., P. Trivedi, B. Kumar and L.S. Palni, 2006. Characterization of a phosphate solubilizing and antagonistic strain of Pseudomonas putida (B0) isolated from a sub-alpine location in the Indian central Himalaya. Curr. Microbiol., 53: 102-107.

Patten, C.L. and B.R. Glick, 1996. Bacterial biosynthesis of indole-3-acetic acid. Can. J. Microbiol., 42: 207-220.

Persello-Cartieaux, F., L. Nussaume and C. Robaglia, 2003. Tales from the underground: molecular plantrhizobacteria interactions. Plant Cell Environ., 26: 189-199.

Ponmurugan, P. and C. Gopi, 2006. In vitro production of growth regulators and phosphate activity by phosphate solubilizing bacteria. Afr. J. Biotechnol., 5: 348-350.

Poonguzhali, S., M. Madhaiyan and T. Sa, 2008. Isolation and identification of phosphate solubilizing bacteria from Chinese cabbage and their effect on growth and phosphorus utilization of plants. J. Microbiol. Biotechnol., 18: 773-777.

Raghothama, K.G., 1999. Phosphate acquisition. Ann. Rev. Plant Physiol. Plant Mol. Biol., 50: 665-693.

Rajkumar, M., R. Nagendran, L.J.K. Wang, H.L. Zoo and $\mathrm{S}$. Kim, 2006. Influence of plant growth promoting bacteria and $\mathrm{Cr}^{6+}$ on the growth of Indian mustard. Chemosphere, 62: 741-748.

Rajkumar, M. and H. Freitas, 2008. Influence of metal resistant-plant growth-promoting bacteria on the growth of Ricinus communis in soil contaminated with heavy metals. Chemosphere, 71: 834-842.

Rani, A., Y.S. Souche and R. Goel, 2009. Comparative assessment of in situ bioremediation potential of cadmium resistant acidophilic Pseudomonas putida 62BN and alkalophilic Pseudomonas monteilli 97AN strains on soybean. Int. Biodeterior. Biodegrad., 63: 62-66.

Rekha, P.D., W. Lai, A.B. Arun and C. Young, 2007. Effect of free and encapsulated Pseudomonas putida CC-R2-4 and Bacillus subtilis CC-pg104 on plant growth under gnotobiotic conditions. Bioresour. Technol., 98: 447-451. 
Remans, R., S. Beebe, M. Blair, G. Manrique and E. Tovar et al, 2008. Physiological and genetic analysis of root responsiveness to auxin-producing plant growthpromoting bacteria in common bean (Phaseolus vulgaris L.). Plant and Soil, 302: 149-161.

Richardson, A.E., 1994. Soil Microorganisms and Phosphorous Availability. In: Soil Biota: Management in Sustainable Farming Systems, Pankhurst, C.E., B.M. Doube and V.V.S.R. Gupta (Eds.). CSIRO, Victoria, Australia, pp: 50-62.

Rodriguez, H. and R. Fraga, 1999. Phosphate solubilizing bacteria and their role in plant growth promotion. Biotechnol. Adv., 17: 319-339.

Sahin, F., R. Cakmakci and F. Kantar, 2004. Sugar beet and barley yields in relation to inoculation with $\mathrm{N}_{2}$-fixing and phosphate solubilizing bacteria. Plant Soil, 265: 123-129.

Saravanakumar, D., C. Vijayakumar, N. Kumar and R. Samiyappan, 2007. PGPR-induced defense responses in the tea plant against blister blight disease. Crop Prot., 26: 556-565.

Saravanan, V.S., M. Madhaiyan and M. Thangaraju, 2007. Solubilization of zinc compounds by the diazotrophic, plant growth promoting bacterium Gluconacetobacter diazotrophicus. Chemosphere, 66: 1794-1798.

Selvakumar, G., M. Mohan, S. Kundu, A.D. Gupta, P. Joshi, S. Nazim and H.S. Gupta, 2008. Cold tolerance and plant growth promotion potential of Serratia marcescens strain SRM (MTCC 8708) isolated from flowers of summer squash (Cucurbita pepo). Lett. Applied Microbiol., 46: 171-175.

Shaharoona, B., M. Naveed, M. Arshad and Z.A. Zahir, 2008. Fertilizer-dependent efficiency of Pseudomonads for improving growth, yield and nutrient use efficiency of wheat (Triticum aestivum L.). Applied Microbiol. Biotechnol., 79: 147-155.

Singh, N., P. Pandey, R.C. Dubey and D.K. Maheshwari, 2008. Biological control of root rot fungus Macrophomina phaseolina and growth enhancement of Pinus roxburghii by rhizosphere competent Bacillus subtilis BN1. World J. Microbiol. Biotechnol., 24: 1669-1679.

Stintzi, A., C. Barnes, J. Xu and K.N. Raymond, 2000. Microbial iron transport via a siderophore shuttle: A membrane ion transport paradigm. PNAS, 97: 10691-10696.

Tank, N. and M. Saraf, 2010. Salinity-resistant plant growth promoting rhizobacteria ameliorates sodium chloride stress on tomato plants. J. Plant Interactions, 5: 51-58.
Thakuria, D., N.C. Talukdar, C. Goswami, S. Hazarika, R.C. Boro and M.R. Khan, 2004. Characterization and screening of bacteria from rhizosphere of rice grown in acidic soils of Assam. Curr. Sci., 86: 978-985.

Tripathi, M., H.P. Munot, Y. Shouch, J.M. Meyer and R. Goel, 2005. Isolation and functional characterization of siderophore-producing lead-and cadmium-resistant Pseudomonas putida KNP9. Curr. Microbiol., 5: 233-237.

Tsavkelova, E.A., S.Y. Klimova, T.A. Cherdyntseva and A.I. Netrusov, 2006. Microbial producers of plant growth stimulators and their practical use: A review. Applied Biochem. Microbiol., 42: 117-126.

Vassilev, N., M. Vassileva and I. Nikolaeva, 2006. Simultaneous P-solubilizing and biocontrol activity of microorganisms: Potentials and future trends. Applied Microbiol. Biotechnol., 71: 137-144.

Vega, N.W.O., 2007. A review on beneficial effects of rhizosphere bacteria on soil nutrient availability and plant nutrient uptake. Rev. Fac. Nal. Agrc. Medellín, 60: $3621-3643$.

Verma, D.P.S. and S. Long, 1983. The molecular biology of Rhizobium-legume symbiosis. Int. Rev. Cytol. Suppl., 14: $211-245$.

Vikram, A. and H. Hamzehzarghani, 2008. Effect of phosphate solubilizing bacteria on nodulation and growth parameters of greengram (Vigna radiata L. Wilczek). Res. J. Microbiol., 3: 62-72.

Vivas, A., B. Biro, J.M. Ruiz-Lozano, J.M. Barea and R. Azcon, 2006. Two bacterial strains isolated from a Zn-polluted soil enhance plant growth and mycorrhizal efficiency under Zn-toxicity. Chemosphere, 62: 1523-1533.

Wani, P.A., M.S. Khan and A. Zaidi, 2007a. Co inoculation of nitrogen fixing and phosphate solubilizing bacteria to promote growth, yield and nutrient uptake in chickpea. Acta Agron. Hungarica, 55: 315-323.

Wani, P.A., M.S. Khan and A. Zaidi, 2007b. Effect of metal tolerant plant growth promoting Bradyrhizobium sp. (vigna) on growth, symbiosis, seed yield and metal uptake by greengram plants. Chemosphere, 70: 36-45.

Wani, P.A., M.S. Khan and A. Zaidi, 2007c. Synergistic effects of the inoculation with nitrogen fixing and phosphate solubilizing rhizobacteria on the performance of field grown chickpea. J. Plant Nutr. Soil Sci., 170: 283-287.

Wani, P.A., M.S. Khan and A. Zaidi, 2008. Chromiumreducing and plant growth-promoting Mesorhizobium improves chickpea growth in chromium-amended soil. Biotechnol. Lett., 30: 159-163. 
Weller, D.M. and R.J. Cook, 1983. Suppression of take-all of wheat by seed treatments with fluorescent pseudomonads. Phytopathology, 73: 463-469.

Yu, Y., X. Chu, G. Pang, Y. Xiang and H. Fang, 2009. Effects of repeated applications of fungicide carbendazim on its persistence and microbial community in soil. J. Environ. Sci., 21: 179-185.

Zahir, Z.A., M. Arshad and W.T. Frankenberger, 2004. Plant growth promoting rhizobacteria: Applications and perspectives in agriculture. Adv. Agron., 81: 97-168.

Zahran, H.H., 2001 . Rhizobia from wild legumes: Diversity, taxonomy, ecology, nitrogen fixation and biotechnology. J. Biotechnol., 91: 143-153.

Zaidi, A. and S. Khan, 2005. Interactive effect of rhizospheric microorganisms on growth, yield and nutrient uptake of wheat. J. Plant Nutr., 28: 2079-2092.
Zaidi, A. and M.S. Khan, 2006. Co-inoculation effects of phosphate solubilizing microorganisms and Glomus fasciculatum on green gram-Bradyrhizobium symbiosis. Turk. J. Agric., 30: 223-230.

Zaidi, S., S. Usmani, B.R. Singh and J. Musarrat, 2006. Significance of Bacillus subtilis strain SJ-101 as a bioinoculant for concurrent plant growth promotion and nickel accumulation in Brassica juncea. Chemosphere, 64: 991-997.

Zaidi, A., M.S. Khan, M. Ahemad and M. Oves, 2009. Plant growth promotion by phosphate solubilizing bacteria. Acta Microbiol. Immunol. Hungarica, 56: 263-284. 